\title{
Advantages and Barriers for the development of the use of Renewable Energy Sources in Latvia
}

\author{
P.Shipkovs ${ }^{1,2}$, G.Kashkarova ${ }^{1}$, K.Lebedeva ${ }^{1}$, L.Migla ${ }^{1,2}$, J.Shipkovs ${ }^{1}$, M.Pankars ${ }^{2}$ \\ ${ }^{1}$ Institute of Physical Energetics \\ Aizkraukles 21, Riga, LV-1006 - Latvia \\ Phone/ Fax number: +371 67553537 \\ Email: shipkovs@edi.lv \\ ${ }^{2}$ Riga Technical University \\ Azenes 16/20, Riga, LV-1048-Latvia \\ Phone: +371 67615191 \\ Email: lana.migla@rtu.lv
}

\begin{abstract}
Enquire Advantages and Barriers for the development of the use of Renewable Energy Sources in Latvia is the Aim of paper. Existing Policy \& Strategy as well as new tendency in the use of renewable energy sources (RES) in Latvia will be presented in the paper. The main directions of the energy policy are aimed at improving the security of energy supply of the country by encouraging diversification of supplies of primary energy resources. Creation of competitive conditions, promotion of the use of renewable and local energy resources and environmental protection also play a substantial role.
\end{abstract}

In accordance with the Latvian "Law on the Energy Performance of Buildings" environmental and economic considerations, as well as binding regulations of the local government and other regulatory enactments, shall be taken into account in designing buildings, in order to evaluate the possibility to use as an alternative solution in these buildings systems, in which RES are used. Latvia is abounds in wood and hydropower.

Papers will describe the using opportunities of the renewable energy resources in Latvian conditions. Recommendations for RES effective and rational use will be presented taking in account new legislation.

\section{Key words}

Renewable energy resources use, renewable energy resources use strategy and policy.

\section{Introduction}

The main directions of the energy policy are aimed at improving the security of energy supply of the country by encouraging diversification of supplies of primary energy resources. Creation of competitive conditions, promotion of the use of renewable and local energy resources and environmental protection also play a substantial role.
The main objectives of the energy policy are to ensure sustainable accessibility to the necessary energy resources and security of supply in order to foster economic growth and improve quality of life; to ensure environmental quality retention and meet the objectives set in the Kyoto protocol of UN FCCC and Latvian Climate Change Program on GHG emissions reduction for years $2005-2010$.

\section{Policy and Strategy for the RES use}

\section{A. Energy policy framework documents:}

\section{1) Guidelines for Energy Sector Development for} 2007-2016

The main bases for Energy policy are: The guidelines to ensure security of supply in the country as the main goal of energy Policy. The increasing of self sufficiency and greater diversification of energy resources supply are the next very important subjects of Energy sector development. Latvia has to search for its own fossil fuels and to increase effective use of renewable sources of energy and energy production in cogeneration (CHP) processes;

2) Guidelines for Use of Renewable Sources of Energy for 2006-2013

Setting targets for the use of RES are:

- $\quad 49.3 \%$ share of RES-E by 2010 ;

- $8 \%$ share of electricity produced in highly efficient CHP using biomass by 2016;

- $\quad 5.75 \%$ share of biofuels in total consumption by 2010;

- $\quad 10 \%$ share of biofuels by 2016 (in comparison to less than $2 \%$ in 2006).

- $\quad 35 \%$ share of RES in the Energy Balance (in comparison to $28 \%$ in 2007). 


\section{B. Legal Framework}

1) EU Directives:

- Directive 2001/77/EC on electricity production from RES;

- Directive 2004/8/EC on the promotion of cogeneration based on a useful heat demand in the internal energy market.

- Directive 2009/28/EC on the promotion of RES usage

\section{2) National laws:}

- Energy Law;

- $\quad$ RES Energy Law (project);

- Electricity market Law;

- Law on the Energy Performance of Buildings;

- Regulations No. 262 on Production of Electricity from Renewable Sources of Energy;

- Regulations No. 221 on Electricity Production in Cogeneration Regime.

\section{Main support instruments}

1) Mandatory procurement of electricity produced from RES on basis of fixed purchase price formulas

- Regulations No. 262 on Production of Electricity from RES (in force since March 2010);

These Regulations (No. 262) indicated criteria's of produced electricity as compulsory purchase trades. If electricity produced of biomass or biogas in power station with installed capacity over $1 \mathrm{MW}$, it is possible to get guaranteed fee of set up power.

- Regulations No. 221 on Production of Electricity in Cogeneration Regime (in force since March 2009).

\section{2) EU Structural Funds}

In accordance with the Latvian "Law on the Energy Performance of Buildings" environmental and economic considerations, as well as binding regulations of the local government and other regulatory enactments, shall be taken into account in designing buildings, in order to evaluate the possibility to use as an alternative solution in these buildings systems, in which RES are used.

\section{3) Investments in the energy sector}

State support in the energy sector is only given to Projects linked to adjustment of heat supply system. The priorities for the use of EU Structural Funds are listed in the Development Plan, these priorities are sub-divided into measures, which in turn are subdivided into activities. It is planned to allocate approximately EUR 140 million in the energy sector from the Cohesion Fund in the next Structural Funds utilization period of 2007-2013. This amount will be distributed to measures for increase of efficiency of district heating systems, for development of cogeneration plants that use biomass and development of wind farms in Latvia.

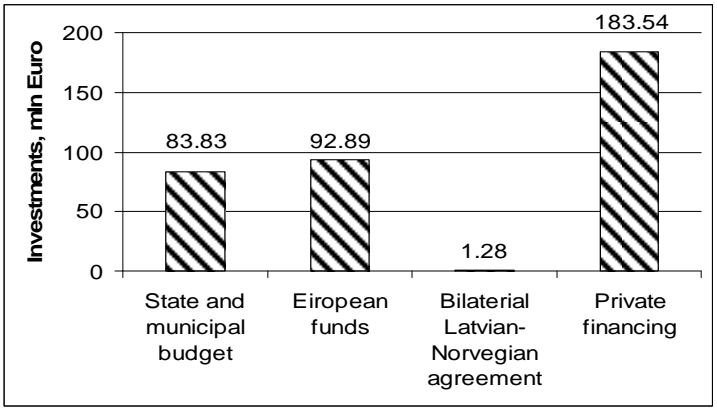

Figure 1. Potential financial sources for development of RES use (2006-2013)

\section{4) A feed-in tariff (FiT)}

A feed-in tariff involves the obligation on the part of a utility to purchase electricity generated by renewable energy producers in its service area at a tariff determined by public authorities and guaranteed for a specific period of time (generally 20 years). A FiT's value represents the full price per $\mathrm{kWh}$ received by an independent producer of renewable energy, i.e. including a premium above or additional to the market price, but excluding tax rebates or other production subsidies paid by the government. Different tariffs can be defined for different technologies (wind, solar, biomass, etc.) or different countries depending on resource conditions (e.g. solar irradiation).

The rate of a FiT is furthermore reduced each year for new installations in order to stimulate decrease in production costs. Feed-in laws have been the primary mechanism used to support RES development in Europe and the US. They have a track record of some two decades and are well established throughout the European Union. At present, they are being applied in 21 EU member countries. While many countries in Europe have introduced a FiT on different levels, only some of them (e.g. Germany) have adopted appropriate rates specifically for PV. Others used inadequate FiT parameters (for instance Austria - too low a ceiling on total installed PV capacity) and thus failed to stimulate significant investor interest.

\section{5) Other support mechanisms}

In EU countries exist significant variety of support mechanisms. Their main goal is to introduce renewable energy sources into the market and to make them as a common source for gaining electricity. It is commonly admitted that activity of scientific circles and informational campaigns connected with demonstration projects play an important role in the RES development. In case of photovoltaic FiT Tariff is the most important and most effective way in creating development in that branch provided that correct designing of FiT law is submitted. 
Investment based support mainly depends on providing investment subsidies, tax credits, and bank loans with beneficial interest rates. Supports mentioned above are significant due to their impact on initial market development. Investment based support has importance in case of expensive technologies and currently it is used in many European countries.

Quota schemes (also called Renewable Portfolio Standard - RPS) oblige the producers of electricity and retail provider to attain a specified minimum level of shares RES in its mix. RPS is commonly combined with the Tradable Green Certificates system (TGC). TGC relies on market competition and therefore is unstable in the matter of price. These certificates being the subject of trade contain additional profit for the renewable user of energy. Tradable Green Certificates system does not favor the most future-orientated and ecological technologies of producing green electricity such as photovoltaic and off-shore wind turbine. Tendering or Competitive Bidding is a transitional mechanism between FiT and RPS. Under a tendering scheme developer of project submits his own proposal and indicates the wholesale price he would like to get for the produced electricity. The one, who offers the lowest production costs of every $\mathrm{kWh}$, will be able to sell electricity for the lower price and will enter a contract which guarantees that electricity will be bought over a defined period of time.

\section{New Energy Policy}

The first proposals are submitted to the Ministry of Economy of Latvia. Some recommendations for the new legislation on effective and rational use of the RES:

there is a well-established national support scheme for production of electricity from RES mandatory procurement applicable to electricity production in wind-, hydro-, biomass- and biogas PP;

- with regard to the RES, we convinced to reach a balance between electricity demand and supply potential from local Power Plants by years 2011 -2012 ;

- to further develop and implement support schemes for highly efficient cogeneration and use of renewable energy resources in the power generation;

- to improve facilitation activities for bio-fuel production and consumption;

- to implement energy efficiency measures;

- to actively participate in EU and other international $R \& D$ projects;

- as a major challenge we regard the upcoming renewable energy policy development on the EU level and the ambitious individual target for Latvia $-42 \%$ by 2020 ;

- $\quad$ to develop pilot projects and implementation.

\section{1) New Latvian Policy on RES}

Overall, the national renewable energy policy is to promote their use, respecting environment and achieving $\mathrm{CO}_{2}$ emission reduction. The main renewable energy policy objectives to be achieved is as follows

- Electricity production of RES is $49,3 \%$ of all produced electricity in 2010 ;

- Renewable energy must be at least $37 \%$ in total energy balance;

- The share of biofuels of all marketed transport fuel should be $5,75 \%$ in 2010 .

The aim of the Government policy is to achieve the balance between electricity demand and supply potential from Power Plants by years 2011-2012;

The goal is to promote maximum energy efficiency measures and supply of the power plants that use local fuels and renewable sources of energy in the highefficiency co-generation cycle.

The remaining part of the required supply capacity will be diversified to other fossil fuels, to prevent overdominance of natural gas.

During the development of cogeneration plants, energy from renewables will increase power capacity potential of transmission and distribution systems. Two support tools have been selected for this purpose:

- compulsory purchase at a specified price, whether in terms of all Latvian electricity consumer payment in proportion of consumption;

- Renewable sources of energy promote the development of cogeneration power plants earmarked for investment in the power structure, the purpose of EU structural funds.

For improvement of RES use and promotion of the development of biomass cogeneration, it is expected to attract the means of EU Structural Funds and support of Cohesion Fund. Till the year 2016 it is expected to attract 8,1 million LVL from the State Budget and 27 million LVL from EU Structural Funds.

RES exploitation strategy is closely connected with the introduction measures of energy efficiency. RES policy includes an integrated approach to energy efficiency issues.

\section{2) RES Law (project)}

Aims and Objectives

Aims of the Law:

- $\quad$ to promote local RES production, use and export;

- to determine stable long term investment environment for production, usage and export of local RES support;

- to contribute reducing technologies of the greenhouse effect and gas emission;

Law challenges to achieve goals:

- Till the year 2020 increase the RES usage in gross final consumption up to $40 \%$ and continue to gradually increase it;

- to promote openness and accessibility of information on energy scope; 
- to establish administrative procedures in RES production and usage;

- $\quad$ to determine the support measures for local RES production and usage.

\section{3) National goals of RES use}

Law enforcement is a specific period till the year 2020 to achieve the following percentage of gross in RES usage:

- $\quad$ till year 2012 not less than 34,08\%;

- $\quad$ till year 2014 not less than 34,82\%;

- $\quad$ till year 2016 not less than 35,93\%;

- $\quad$ till year 2018 not less than 37,04\%;

- $\quad$ till year 2020 not less than $40 \%$.

\section{Conclusion}

Recommendations for RES effective use were prepared upon the realized projects and analyses of the National RES Policy and Strategy.

Within the frame of the State Research Program's Project "'Research and development of the renewable energy resources production and consumption technologies for climate changes generated by energy sector mitigation", suggestions were worked up also for rational RES use. Legation for RES use in Latvia are improvable, there must be realized a lot of corrections to making it more precise, but it is good start to promote the Latvian Power Industry independence of the Energy importers.

\section{References}

[1] Latvian Energy Law (03.09.1998).

[2] P.Shipkovs, G. Kashkarova, I. Purina, K. Lebedeva, M.Jirgens, A.Zigurs, A.Cers. "Financing schemes for biomass in Latvia". World Sustainable Energy Days, Wels, Austria, 5.3.7.3.2008., CD proceedings, 9 pp.

[3] P.Shipkovs. „RES in Latvia policy and strategy”. Workshop „Data Gathering on Renewable Energies for New Member States and Candidate Countries", 13-15 November 2007, Istanbul, Turkey. Book of proceedings, EUR 23558 EN-2008, 300-319 pp.

[4] Regulations No. 262 on Production of Electricity from RES (March 2010);

[5] Energy Efficiency Law (18.04.2007.). 